\title{
SONARAVNI RAZVOJ (NAPREDEK) IN GEOGRAFIJA
}

\author{
Plut Dušan \\ Oddelek za geografijo, Filozofska fakulteta Univerze v Ljubljani \\ Aškerčeva 2, SI-I000 Ljubljana, Slovenija \\ e-mail: dusan_plut@t-2.net
}

Izvirni znanstveni članek

COBISS 1.01

\section{Izvleček}

Obseg in intenzivnost različnih oblik degradacije geografskega okolja in njegovih sestavin podčrtuje potrebo po gospodarskemu razvoju, ki bo upošteval značilnosti okolja. Za povečevanje okoljske sestavine človekove blaginje ne zadošča zgolj pasivno zasnovano varstvo geografskega okolja. Geografija sonaravnega razvoja kot raziskovalno polje in učni predmet poudarja pomen pokrajinskim potezam in procesom čim bolj prilagojenega, sonaravnega vzorca poselitve, gospodarstva, infrastrukture in pokrajinske rabe.

Ključne besede: geografsko okolje, okoljska trajnostnost, redefinicija razvoja, sonaravni razvoj, geografija sonaravnega razvoja.

\section{SUSTAINABLE DEVELOPMENT (PROGRESS) AND GEOGRAPHY}

\begin{abstract}
The extent and intensity of different forms of degradation of geographical environment and its constituents prove the need for such economic development which will take account of environmental features. In order to increase the environmental component of human welfare, only passively devised protection of geographical environment is not sufficient. Geography of sustainable development both as an area of research and as a subject in the curriculum, lays emphasis on the significance of landscape features and on the processes of sustainable pattern of settling, economy, infrastructure and landscape use, as well adjusted as possible.
\end{abstract}

Key words: geographical environment, environmental sustainability, redefinition of development, sustainable development, geography of sustainable development. 


\section{UVOD}

Med znanstveniki, ki raziskujejo planetarni ekosistem ni več nobenega dvoma, da je prihodnost človeštva in kakovost življenja odvisna od naše zmogljivosti za doseganje trajnega ravnovesja z globalnim okoljem. Večina znanstvenikov je prepričanih, da sedanja gospodarska rast in razvojni vzorci ne morejo trajati v neskončnost, potrebni so tudi novi pristopi k rabi prostora in virov okolja. V primeru nadaljevanja sedanjih prebivalstvenih in gospodarskih trendov se naj bi v 21. stoletju svetovno prebivalstvo podvojilo, gospodarska dejavnost pa povečala za pet- do desetkrat, kar bi povzročilo nepredstavljiv obseg degradacije okolja in svetovnih virov (Marsh in Grossa 2002, 35). Globalno gospodarstvo je torej že preseglo oskrbne zmogljivosti planeta, človeštvo je v 21. stoletju vse bližje upadu, morda celo propadu (Brown 2006), med državami sveta pa so velike socialne in ekonomske razlike ter okoljski pritiski na prebivalca (Vintar Mally 2006).

Narašča spoznanje, da se izčrpavanju in degradaciji okolja lahko izognemo zgolj z okolju in naravi prilagojeno dejavnostjo, ki bo ohranila ključne planetarno pomembne vire ter življenjske oskrbne sisteme. Rekonstrukcija gospodarstva pa zahteva spremembe v vseh poljih človekove dejavnosti, načinu organizacije podjetništva in svetovnega gospodarstva ter trgovine, vključno s spremembami v sistemu vrednot. Prostorsko udejanjanje trajnostne paradigme postavlja tudi pred geografijo in njene panoge številne nove in prenovljene vsebine, veliko priložnost za njeno organsko reintegracijo in družbeno afirmacijo.

\section{GEOGRAFIJA IN VARSTVO OKOLJA}

Radinja (1974) je zelo zgodaj opozoril, da naj geografija poudarja splošni problem življenjskega okolja in iskanje poti do ustreznega ravnovesja med zahtevami, ki jih na eni strani prinaša prebivalstvena rast, tehnični napredek in težnja po višjem življenjskem standardu ter na drugi strani možnostmi, da se ohrani biološko zdravo in estetsko sprejemljivo okolje. Geografija lahko s konkretnimi kompleksnimi regionalnimi analizami največ prispeva $\mathrm{k}$ praktičnemu vzpostavljanju občutljivega in dinamičnega pokrajinskega ravnovesja. Tako postaja ponovno aktualno tudi regionalnogeografsko zasnovano proučevanje geografskega okolja, njegovo varovanje in izboljšanje. Le - tega geografija obravnava kot splet naravnih pojavov in antropogenih elementov $\mathrm{v}$ prostorski stvarnosti, $\mathrm{v}$ katerem veljajo tako naravne kot družbene zakonitosti razvoja, ki jih je potrebno upoštevati pri varovanju (geografskega) okolja. Ne glede na to, da smo ljudje sami sestavni del narave, pa pripada človeški družbi vloga glavnega in zavestnega gibala preobrazbe prirode. Prav zaradi teh tesnih vezi moramo pojmovati geografsko okolje v najširšem smislu kot naravno okolje, antropogeno preoblikovano naravno okolje (obdelovalne površine, gojeni gozd, urejene vodne razmere) in pretežno antropogeno ali tehnogeno (naselja, predvsem mesta, industrijske in prometne naprave) (Ilešič 1979, 320, 321).

Po mnenju Radinje $(1974,111)$ je geografija kratko malo veda o okolju, onesnaževanje, zastrupljanje oziroma degradacija okolja so le določene razvojne faze, razvojne oblike okolja. Geografija se žariščno usmerja na proučevanje pokrajinskih (prostorskih) posledic (učinkov) 
dejavnosti človeka v okolju. Geografijo zanimajo tiste naravno in družbenogeografske značilnosti pokrajin (regij, območij), ki so pomembne za razlago degradacije okolja in njegovih sestavin (Špes 1994), vključno z ranljivostjo okolja na posege človeka (Špes in drugi 2002). V metodološko in vsebinsko ospredje postavlja geografija naslednje vidike degradacije okolja (Radinja 1972, 1974):

- celostnost okolja in neobhodnost kompleksnega proučevanja

- vzajemnost in medsebojna soodvisnost prirodnih in družbenih procesov

- medsebojno prepletanje in součinkovanje prirodnih in družbenih procesov

Varstvo (geografskega) okolja označujejo prizadevanja za njegovo ohranjanje, izboljšanje kakovosti in preprečevanje njegove degradacije kot celote ter njegovih sestavin (naravnih in antropogenih). V širšem pomenu vključuje tudi varovanje (zaščito) naravnih virov, pokrajinske in biotske raznovrstnosti, narave, naravne in kulturne dediščine (Plut 1998). Radinja (1974) se zavzema za varstvo okolja v najširšem pomenu in sicer za celotno okolje (geografsko, človekovo, življenjsko) z njegovimi prirodnimi in antropogenimi sestavinami, vključno s smotrnim urejanjem in preurejanjem tega okolja. Po mnenju Ilešiča (1979) varstvo okolja zajema zaščito narave, fiziološko zdravega življenjskega okolja (zlasti zraka, vod, rastja), varstvo kmetijske zemlje, zaščito gospodarsko uporabnih naravnih bogastev, antropogenih in kulturnih sestavin okolja (npr. zelenic, parkov, cerkva, gradov itd.). Varstvo okolja pomeni torej tako varovanje in izboljšanje, saj so stopnje njegove preobrazbe zelo različne (Radinja 1987, 22).

Varstvo geografskega okolja je potrebno pojmovati ne le kot pasivno zaščito okolja, temveč tudi kot njegovo preudarno aktivno urejanje in sonaravno (naravnim zakonitostim prilagojeno) gospodarjenje z njegovimi sestavinami. Označuje postopen premik od antropocentričnega pojmovanja geografskega okolja (človek kot gospodar narave) k ekocentričnemu, pogledu na svet kot varen in trajen dom vseh vrst ter bodočih generacij. Oblikuje se ti. sonaravna paradigma, ki civilizacijski napredek ocenjuje tudi z vidika trajnostnega ohranjanja pogojev kakovosti življenja človeštva in drugih vrst. Varstvo geografskega okolja v širšem pomenu je eden od temeljnih pogojev trajnostnega sonaravnega razvoja (gospodarski napredek v okviru omejitev okolja), saj omogoča zanesljivost zadovoljevanja potreb sedanje generacije brez ogrožanja življenja prihodnjih generacij ter drugih vrst. Zato je potrebno razen pokrajinskih učinkov posegov opozarjati tudi na trende, torej osnovne smeri pokrajinskih razvojnih procesov.

Temeljna načela varstva okolja so:

- celovita sanacija degradiranih pokrajin in pokrajinotvornih sestavin (voda, zrak itd.)

- preprečevanje nastajanja novih virov in območij onesnaževanja

- smotrno gospodarjenje z naravnimi (okoljskimi) viri

- gospodarski razvoj in pokrajinska raba v okviru omejitev geografskega okolja (prostorskih, surovinsko - energetskih in samočistilnih)

- trajno ohranjanje narave, naravnih virov in pokrajinske raznovrstnosti za bodoče generacije

Celostno razumevanje in proučevanje degradacije in varstva geografskega okolja potrjuje smisel geografije kot kompleksne vede ter njenega osrednjega predmeta - geografskega okolja 
(pokrajine) (Radinja 1974, 38). Varstvo okolja pa je v sodobnem svetu vitalnega pomena ne le za kakovost našega življenja, temveč tudi za preživetje prihodnjih generacij (Vovk Korže 1997).

\section{GEOGARFSKA OPREDELITEV TRAJNOSTNOSTI IN SONARAVNOSTI}

Organiziranost dejavnosti v skladu z ekosfero dejansko določa trajanje človeške civilizacije (Kupchella in Hyland 1996). Trajnost obstoja človeške vrste bo določala sposobnost človeštva, da se trajno prilagodi sistemu narave, nasilji človeka do narave in sočloveka, barbarizem dveh obrazov, pa nadomesti dinamično sožitje človeka z naravo, okoljem in svetovni mir. Globalnost ekonomskih, socialnih in okoljskih problemov zahteva globalen odgovor, stkan kot mreža ustreznih lokalnih in regionalnih odgovorov.

Sodobno pojmovanje človekovega napredka, človekove blaginje vključuje povečanje ekonomske, socialne in okoljske blaginje. Za povečevanje okoljske sestavine človekove blaginje torej ne zadošča zgolj pasivno zasnovano varstvo geografskega okolja, temveč tudi ti. razvoj geografskega okolja oziroma trajna raba naravnega (okoljskega) kapitala. Trajnostnost (sustainability) praviloma označuje ohranjanje zmogljivosti povezanega sistema ekonomije in okolja za stalno (trajno) zadovoljevanje potreb in želja človeštva v dolgi prihodnosti, kar naj bi omogočil trajnostni razvoj (sustainable development) (Common in Stagl 2005, 8, 9).

$\mathrm{Z}$ uporabo besede trajnostnost želimo pri varstvu geografskega okolja torej podčrtati cilj, težnjo trajnega oziroma trajnostnega ohranjanja naravnega (okoljskega) kapitala in hkrati dolgoročno (trajno) zasnovanega delovanja gospodarstva in celotne družbe. V tem pomenu je primerna samostojna uporaba besede trajnostnost. Prav tako je uporaba pojma trajnostnost primerna, če želimo poudariti širšo skrb za dvig široko pojmovane kakovosti življenja, enakost ljudi v sedanjosti in prihodnosti, seveda $v$ okviru zmogljivosti okolja, narave (Plut 2005). Vendar se v različnih znanostih pojem trajnostnosti različno tolmači, definira. Načelo trajnostnosti se tako obravnava enoplastno ( $\mathrm{z}$ vidika okolja in narave) ali večplastno (z vidika okolja in narave, gospodarstva in družbe oziroma sociale). V obeh primerih pa je ključno izhodišče prilagajanje človeštva zmogljivostim (omejitvam) okolja in narave. Različnost pojmovanja trajnostnosti torej povzroča vsebinske in terminološke težave.

Navedena večpomenskost pojma trajnostnosti je za geografijo dodaten razlog za rabo pojma sonaravnost (sonaravno), ki je ožji, veže se na udejanjanje načel varstva okolja in narave, torej na okoljsko trajnostnost. Lah $(2002,175)$ tako definira sonaraven-usklajen z naravo, uravnotežen z okoljem in tudi dolgoročno razvojno usklajen. V Slovenskem pravopisu $(2001,1458)$ so besede sonaraven, sonaravno gospodarjenje z gozdovi, /skladno z naravo/ sonaravnost; sonaravno pridelana hrana /naravna/. Beseda sonaravno (sonaravnost) v slovenskem jeziku prednostno označuje način delovanja, gospodarjenja, ki je skladen $\mathrm{z}$ naravo, pojem trajnostnost (trajne vrednote umetnine) pa označuje časovno razsežnost. Za povečevanje okoljske sestavine človekove blaginje ne zadošča zgolj pasivno zasnovano varstvo geografskega okolja, temveč tudi »razvoj« geografskega okolja oziroma trajna raba naravnega (okoljskega) kapitala. $\mathrm{Z}$ besedo sonaravnost torej podčrtujemo način (usmeritev, 
smernica) za ohranjanje naravnega (okoljskega) kapitala, torej naravi in (geografskemu) okolju trajno (primerneje dolgoročno) prilagojeno delovanje (dejavnosti) družbe (Plut 2005).

Sonaravnost kot postopno uravnoteževanje delovanja družbe (človeka) z naravo in okoljem je torej proces, od nižje (šibke) k višji (strogi, močni) stopnji sonaravnosti skupnosti, gospodarstva. Sonaravni način materialnega življenja družbe, države, regije naj bi omogočil čim bolj dolgotrajno, torej trajnostno (trajno) delovanje in obstoj družbe. Sonaravnost delovanja družbe je torej način, smernica (kažipot, smerokaz in hkrati pot) za dosego trajnostnosti kot medčasovne (medgeneracijske) kategorije, zgolj idealnega oziroma idealiziranega (zaradi neizogibne entropije vsake materialne dejavnosti) cilja. Današnje pojmovanje sonaravnosti ne pomeni zgolj živeti ob in od narave na trajnosten način. Dejansko daje podlago za preureditev človeške družbe po vzoru naravnih, samoregulirajočih in na dolgi rok stabilnih kompleksnih sistemov (Macarol 2001, Common in Stagl 2005). Slovenski Geografski terminološki slovar (2005) žal ne vsebuje pojma trajnostnost in/ali sonaravnost. Marsh in Grossa $(2002,437)$ pa trajnostnost (sustainability) geografsko opredeljujeta in sicer kot zmogljivost izgradnje sistemov rabe zemljišč, ki so okoljsko v ravnovesju in trajni. V ospredje torej postavljata geografske vsebine, ki ustrezajo pojmu (geografske) sonaravnosti, torej sonaravne zasnove sistemov rabe zemljišč.

$Z$ vidika geografije kot vsebinsko zelo široke in razvejane znanstvene discipline je torej umestno v njeno polje vključite širše pojmovan koncept trajnostnosti/sonaravnosti, ki razen okoljske obsega tudi gospodarsko in družbeno (socialno) sestavino, ki jo obravnavajo druge znanosti, v posameznih poudarkih pa tudi ekonomska, socialna in regionalna geografija. Tako mora sodobna ekonomska geografija pri načrtovanju prostorske organizacije in obsega proizvodnje upoštevati načela trajnostnosti/sonaravnosti in zakone termodinamike (Hudson 2000, 11). Zaradi znanstveno-raziskovalnih prednosti geografije pa je umestno okoljski trajnosti z vidika geografskih sonaravnih in razvojno zasnovanih poudarkov (prostorski in regionalni razvoj) nameniti večjo pozornost, v smeri novega raziskovalnega polja in učnega predmeta-geografije sonaravnega razvoja/napredka. Celostni razvoj v smeri izboljševanje kakovosti življenja, blagostanja (ekonomska sestavina z BDP je zgolj ena stranica blagostanja) lahko opredelimo kot humani napredek posameznika, človeštva.

Predlagamo torej, da se pri geografskemu konceptu trajnostnosti/sonaravnosti (geografska) trajnostnost opredeljuje kot načelo in (geografska) sonaravnost kot način (praksa) udejanjanja trajnostnosti. Udejanjanje načela trajnostnosti omogoča trajnostni sonaravni razvoj (napredek), katerega ustanove in raziskovalci prav tako različno pojmujejo in definirajo.

Okvirna ocena»dovoljenih«posegovčlovekavgeografskookolje(pokrajino)določenega območja naj bi izhajala tudi iz študije (ocene) ranljivosti okolja, ki jo določa občutljivo, dinamično razmerje med pokrajinsko občutljivostjo (nosilnostjo) okolja (regeneracijske in nevtralizacijske zmogljivosti okolja) ter obremenjevanjem okolja z različnimi emisijami (trdnimi, tekočimi in plinskimi) (Špes in drugi 2002). Antropogeni posegi (poselitev, gospodarstvo, infrastruktura, pokrajinska raba) spreminjajo pokrajinsko ranljivost (Špes in drugi 2002), ki je torej zaradi posegov človeka zelo dinamična, spreminjajoča značilnost določenega prostora, pokrajine, regije. Dinamičnost, spremenljivost ti. ranljivosti pokrajine je potrebno upoštevati pri prostorskem in regionalnem načrtovanju. 
Geografska zasnova sonaravnosti hkrati zahteva, da posegi v določenem geografskem območja nimajo negativnih posledic $\mathrm{v}$ sosedstvu (prostorski razmik) ali pa se okoljske posledice pojavijo kasneje (ti. časovni razmik).

Pojem trajnostnost je torej dejansko širši (obsega zlasti gospodarsko, družbeno in okoljskom trajnostnost) in večpomenski kot pojem sonaravnost, ki se veže na udejanjanje načel varstva okolja in narave, torej na okoljsko trajnostnost. Z besedo sonaravnost torej podčrtujemo način (usmeritev, smernica) za ohranjanje naravnega kapitala, naravi in okolju trajno (primerneje dolgoročno) prilagojeno delovanje (dejavnosti) družbe.

\section{OKOLJSKA REDEFINICIJA RAZVOJA IN GEOGRAFIJA}

Koncept razvoja v klasičnem pomenu predpostavlja rast, koncept trajnostnosti ohranjanja pogojev življenja pa je zasnovan na ekosistemskem izhodišču, da rast ni mogoča na omejenem planetu. Potrebujemo torej tak koncept, način optimalnega gospodarskega in socialnega razvoja, ki bo upošteval naravno, ekosistemsko ravnovesje in omejitve (bolje zmogljivosti). Torej ne bo zasnovan na neskončni količinski rasti, temveč na kakovosti.

Svetovno gospodarstvo je odvisno od stanja in spreminjanja geografskega okolja, njegovih sestavin in procesov. Medsebojna odvisnost postaja vse bolj izrazita, izčrpavanje naravnih virov in preseganje samočistilnih sposobnosti okolja v lokalnih, regionalnih in celo planetarnih razsežnostih (npr. spremembe podnebja in tanjšanje ozonske plasti v stratosferi) pa kaže, da človeška vrsta ne upošteva univerzalnih prostorskih, surovinsko - energetskih in ekosistemskih omejitev (omejenih zmogljivosti, sposobnosti) geografskega okolja, ki so (Plut 2004):

- prostor

- naravni viri (obnovljivi in neobnovljivi, surovine in energija)

- samočistilne (nevtralizacijske in regeneracijske) zmogljivosti

Za načrtovanje udejanjanja okoljske, gospodarske in socialne (družbene) trajnostnosti so ključne: a) potrebe človeka, b) okoljske omejitve, c) gospodarsko-socialna varnost in d) medgeneracijska pravičnost (odgovornost). Civilizacijska sporočilna nota trajnostnostno sonaravne paradigme je dejansko zelo radikalna, saj celotno dosedanjo zgodovino človeške vrste ključno označuje kolonizacija in količinska rast, a tudi odsotnost intelektualnih ali institucionalnih zmogljivosti ter etičnih vodil za doseganje ravnovesja med materialnimi potrebami človeštva in zmogljivostjo narave.

Sodobna, okolju naklonjena razvojna paradigma spoštuje naravne omejitve, njen cilj pa ni nasprotovanje fizikalnim in biokemičnim zakonitostim, temveč z njimi koordinirati družbene zakonitosti (Radej 2001). Celotna blaginja države in posameznika je dejansko sestavljena iz gospodarske, socialne in okoljske blaginje. Prav slednja pa je bila prepuščena ekonomski stihiji, kar se kaže v prekomerni rabi naravnih virov, storitev okolja in s tem povezani degradaciji sestavin okolja. Rast BDP (ključni kazalec gospodarske trajnostnosti) je po trajnostni paradigmi želena, a trajno sprejemljiva le v primeru, da je odraz kakovostnega razvoja in jo ne spremlja hkratno izčrpavanje naravnih virov in povečevanje pritiskov, one- 
snaževanje okolja ter povečevanje socialne nepravičnosti oziroma zmanjševanje socialne varnosti dela prebivalcev.

Okoljsko zasnovan razvoj pa ne predpostavlja le zavračanje dominantnega razvojnega modela, temveč tudi drugačno definicijo razvoja. Chodorkoff (2004) radikalno postavlja predpostavko, da je temeljna redefinicija »razvoja« predpogoj preživetja planeta. Ključna elementa nove definicije razvoja morata vključiti kvaliteto namesto kvantitete in kulturološko sodelovanje prebivalcev ter njihovih skupnosti (Chodorkoff 2004, 1). To pomeni, da morajo same skupnosti, ob aktivnem sodelovanju njihovih prebivalcev, od države in trga prevzeti kontrolo razvojnega procesa. Globalno širjenje proste trgovine in eksponenčna rast hegemonije kapitala streže ideologiji rasti in ekspanziji, kar zahteva kritično analizo bazičnih postulatov "razvoja". Drastično je potrebno torej opozoriti na paradoks obstoječega gospodarskega modela »rasti ali smrti« v obdobju izčrpavanja virov okolja in pretečega slabšanja kakovosti okolja ter podnebnih sprememb. Temeljni izziv za gradnjo nove ekonomije je naslednji (Brown 2006, 15): trg mora prepoznati ti. okoljsko resnico. Sedanje globalno gospodarstvo v cene dobrin ne vključuje okoljskih stroškov. Pesimistična in radikalna protiglobalistična razmišljanja pa močno dvomijo glede predpostavke, da je tržno gospodarstvo kot tako sploh sposobno prepoznati okoljsko resnico, vendar celovite alternative še ne ponujajo.

Izhajamo torej iz predpostavke, da je trajnostna (sonaravna) paradigma primerna osnova za drugačen razvojni model človeštva 21. stoletja, ki pa se že zelo različno definira. Z geografskega, prostorskega in okoljskega vidika je potrebno poudariti, da trajnostni razvoj ni vsebinsko optimalen prevod »sustainable develoment«. Tudi po mnenju Pirnata in Anka $(2001,14)$ takšen prevod ni najbolj posrečen, katere pomen bi bilo po njunem mnenju bolje opredeliti kot npr »zadržan, vzdrževan... » saj ne govorimo toliko o časovni dimenziji (trajno...večno).

Geografski terminološki slovar (2005) poskuša očitno geografsko zadrego rešiti tako, da tudi terminološko ločuje med vsebino trajnostnega, trajnostno sonaravnega in sonaravnega razvoja. Trajnostni razvoj se pojmuje kot razvojno usmeritev človeške družbe, ki je usklajena, uravnotežena z naravnimi razmerami ter ohranja okolje, naravne vire za prihodnost (Geografski terminološki slovar 2005, 399). Navedena definicija vsebinsko pokriva (zgolj) okoljsko trajnostnost, njeno udejanjanje v okviru okolju prilagojene razvojne usmeritve človeške družbe.

Širše pa je definiran trajnostni sonaravni razvoj, saj je opredeljen kot skladen regionalni razvoj v okviru nosilnosti okolja in smotrne rabe vseh razpoložljivih gospodarskih, infrastrukturnih in človeških virov (Geografski terminološki slovar, 2005, 399). Razen udejanjanja okoljske trajnostni namreč s smotrno rabo gospodarskih, infrastrukturnih in človeških virov in regionalnega razvoja kot takega vključuje tudi vsebine gospodarske in posredno družbene trajnostnosti. Ker razen okoljske trajnosti poudarimo tudi ekonomske in socialne značilnosti regionalnega razvoja, bi bilo verjetno bolj umestno govoriti o trajnostno sonaravnem regionalnem razvoju.

Lah $(2002$, 176) podobno definira pojem sonaravni trajnostni razvoj (sustainable development) kot uravnoteženi sonaravni razvoj z ustreznimi proizvodnimi in storitvenimi dejavnostmi, ki hkrati omogočajo ohranitev ekosistemsko stabilne in biotično raznovrstne 
narave, izboljšanje človekovega razvoja in zagotovitev primerne blaginje prebivalstva in skupnosti, kar vse naj bo materialna in kulturna dediščina tudi za zanamce. Sonaravni trajnostni razvoj po navedeni definiciji vključuje okoljsko (posebej poudarjeno), gospodarsko in socialno polje ter posebej izpostavi tudi medgeneracijsko odgovornost. Za vse tri navedene definicije trajnostno sonaravnega oziroma sonaravno trajnostnega razvoja je značilno, da so širše, vsebinsko trajnostno troplastno (okoljsko, gospodarsko in družbeno) zasnovane in kot take posredno ali neposredno etično zasnovane (medgeneracijska enakost). Tako so vsebinsko podobne Gilpinovi $(1996,206)$ splošni definiciji »sustainable development«: razvoj, ki dolgoročno omogoča ekonomske, socialne (družbene) in okoljske koristi, ob upoštevanju potreb življenja in prihodnosti generacij.

Tudi ekološka ekonomista Common in Stagl (2005, 372, 373) gospodarsko, okoljsko in socialno (družbeno) polje prepoznavata kot ključne, soodvisne sestavine »sustainable development«. Trajnostno sonaravni razvoj vključuje torej gospodarski razvoj, zaščito naravnih virov in okolja ter socialni razvoj. Usmerjen je na izboljšanje kakovosti življenja vseh prebivalcev sveta brez naraščanja rabe naših naravnih virov preko planetarne nosilne zmogljivosti, zahteva različne ukrepe v vsaki od regij sveta (Common in Stagl 2005, 372). Tako opredeljene, torej široko zasnovane definicije trajnostno sonaravnega razvoja so vsebinsko blizu sistemsko, regionalno zasnovanemu gledanju geografije na razmerje družba-geografsko okolje.

Sonaravni razvoj je definiran kot razvoj človeške družbe, zlasti gospodarski, ki je skladen z naravo, pokrajino, njuno zmogljivostjo (Geografski terminološki slovar 2005, 364). Vsebinsko aplikativno je opredeljen na primeru turizma, kjer se sonaravni turizem pojmuje kot turizem, skladen z obiskano naravo, pokrajino, njuno zmogljivostjo, pri katerem individualni gostje spoštujejo značilnosti okolja in se jim prilagajajo (Geografski terminološki slovar 2005, 364). S tega vidika lahko upravičeno predpostavljamo, da je z besedno povezavo sonaravni razvoj poudarjeno konkretno, praktično udejanjanje (zgolj) okoljske trajnostnosti.

Geografsko razumevanje udejanjanja načela trajnostnosti v ožjem (okoljskem, pokrajinskem) pomenu izhaja iz prepoznavanja pomena zmogljivosti oziroma omejitev okolja (vključno s prostorsko dimenzijo) za sonaravno prostorsko organizacijo delovanja družbe (poselitve, dejavnosti, rabe zemljišč), ki so: 1. velikost ozemlja; 2. naravni viri (obnovljivi in neobnovljivi); 3. samočistilne sposobnosti geografskega okolja oziroma sestavin okolja in 4) pokrajinske ranljivosti kot skupne rezultante pokrajinske občutljivosti in dosežene stopnje obremenjenosti ali onesnaženosti. V interdisciplinarno zasnovano naravoslovno (biološko, fizikalno, kemijsko, hidrološko itd.) pojmovanje okoljske trajnostnosti/sonaravnosti (kot načela in prakse) vnaša geografija zlasti: a) prostorsko razsežnost-omejenost prostora in b) pokrajinsko razsežnost-spremembe pokrajinske občutljivosti zaradi sprememb pokrajinske rabe, poselitve, gospodarske sestave itd.

Šibka sonaravnost poudarja možnost zamenjave naravnega kapitala s človeškim, ustvarjenim, močna sonaravnost pa poudarja nezamenljivost posameznih oblik naravnega kapitala za trajno in varno delovanje planetarnega ekosistema. Funkcij življenjsko oskrbnih sistemov narave namreč ni mogoče nadomestiti, vire okolja je torej potrebno ohranjati, varovati. Modeli razvoja, zasnovani na omejitvah rasti, se osredotočajo na močno, modeli neskončne rasti pa na šibko sonaravnost. Številni ekološki (okoljski) ekonomisti sodijo, da 
neoklasična ekonomija s perspektivo šibke sonaravnosti ni dolgoročno primerna. Z uvedbo ti. kritičnega naravnega kapitala (npr. brezkompromisno ohranjanje ključnih vrst, a možnost spreminanja drugih elementov ekosistema), ki prepoznava nezamenljivost nekaterih vrst naravnega kapitala, se je pristop šibke sonaravnosti močno približal močni sonaravnosti (Common in Stagl 2005, 378).

Geografa Marsh in Grossa $(2002,35)$ sta torej sonaravni razvoj (sustainable development) opredelila kot razvoj, ki zmanjšuje okoljske pritiske in ohranja bazo virov, zasnovan pa je na prepoznavanju nepovratnih škod v okolju in degradaciji baze virov sedanjega razvojnega modela. Tudi geograf Kemp $(2004,418)$ sonaravni razvoj pojmuje kot razvoj, ki je ekonomsko in okoljsko soglasen, torej zadovoljuje potrebe sedanjega svetovnega prebivalstva brez ogrožanja prihodnjih generacij. Hkrati upravičeno poudarja, da sonaravni razvoj dejansko ni nekaj vsebinsko novega, saj je sonaravnost vedno bila del vseh naravnih sisitemov in se kaže v njihovem značilnem ravnovesju (Kemp 2004). Tudi zelo intenzivni naravni procesi lahko uničijo ravnovesje, ki je nujno za ravnovesje, sedanji vzroki ogrožanja ravnovesja pa so rezultat populacijskega pritiska in dejavnosti na naravne vire.

Osnovna geografska opredelitev sonaravnega razvoja oziroma napredka izhaja iz težnje k doseganju kakovostnega, zdravega okolja in ohranjanja naravnih virov (naravnega kapitala), ki omogoča dolgoročen obstoj človeštva in drugih vrst. Aplikativna definicija sonaravnega razvoja pa postavlja v ospredje težnjo k zmanjševanju antropogenih energetsko-surovinskih tokov in drugih pritiskov na raven, ki ne presega regeneracijskih in nevtralizacijskih zmogljivosti okolja ter ohranja pokrajinsko in biotsko raznovrstnost.

Ekonomski geograf Hanink (1997) pa kot alternativni svetovni gospodarski pristop ocenjuje ti. koevolucijski gospodarski razvoj, zasnovan na procesih manjšega, lokalno in regionalno prikladnega obsega gospodarstev. Koevolucijski razvoj poteka preko interakcije lokalne kulture in lokalnega okolja v proizvodnih tehnologijah, ki so ugodne, prikladne glede na izbrano proizvodnjo, hkrati pa jih označujejo zelo majhni vplivi na okolje. Metode proizvodnje in tehnologije naj bi bile prilagojene lokalnim razmeram, pospeševanje regionalne rasti in razvoja naj bi potekalo v trajnostno sonaravni obliki.

Države v razvoju z več kot petimi milijardami prebivalcev imajo pravico do razvoja (Kirn 2004). Vendar bo prišlo do izjemne degradacije pokrajine, okolja in narave, če bo za doseganje blaginje bogatejših držav uporabljen dosedanji klasičen razvojni model. Redifinicija razvoja je torej okoljsko zasnovana, izhaja iz prostorskih, snovno-energetskih in samočistilnih omejitev materialne dejavnosti človeštva.

\section{RAZVOJNE FAZE POKRAJINE - (LE) LINEARNO MERILO NAPREDKA}

Po mnenju M. M. Klemenčiča $(1997,25)$ je za razvoj pokrajine značilna izmenjava obdobij uravnoteženega in neuravnoteženega razvoja. V zgodovini človeštva v širokem loku razvoja družbe sodobne, civilizacijsko (tehnološko) najbolj razvite družbe zapuščajo na zemeljskem površju najmočnejše odtise. Tako lahko sledimo številnim stopnjam preobrazbe pokrajine, geografskega okolja, od komaj spremenjenega naravnega okolja pri naravnih ljudstvih do 
izrazito antropogeniziranega (tehniziranega) v gospodarsko najbolj razvitih državah. Če vzamemo razvojni lok družbe kot napredek, potem si po mnenju M.M. Klemenčiča (1997, 26) razvoj pokrajine (geografskega okolja) lahko predstavljamo kot vzpenjajoče stopnice. Za pokrajino na višji razvojni stopnji smatramo tisto, za obstoj katere je potreben bolj celovit in zapleten splet razvojnih dejavnikov, kot za pokrajino na nižji razvojni stopnji.

Marsh in Grossa (2002) sta z geografskega vidika definirala razvoj kot gospodarsko rast, ki pa vključuje tudi spremembo pokrajinske rabe v smeri večanja ekonomsko produktivne aktivnosti. Vendar opozarjata, da razvoj hkrati povečuje pozidanost prostora, ti. pokrajinsko gostoto (pozidava, večja gostota prebivalcev, zaposlenih itd.) ter okoljsko degradacijo. $\mathrm{Na}$ splošno sta povečevanje gospodarskega sistema (proizvodnje, potrošnje) in rast svetovnega prebivalstva ključni gonilni sili razvoja, ki pa hkrati po številnih znakih presega zmogljivosti planet, torej prihodnjim generacijam ne omogoča ohranjanje preživetveno ključnih pogojev življenja (Marsh in Grossa 2002, 6).

Glede na obstoječo stopnjo antropogene preobrazbe številnih pokrajin sveta, ki so v fazi pokrajinske degradacije in izčrpanih virov okolja pa sodimo, da za navedeno razvojno fazo pokrajine uporaba pojma napredka (kot to velja za razvoj družbe) ni (več) umestna. Očitno je degradirana pokrajina oziroma večplastno degradirano geografsko okolje na začetku 21. stoletja odraz neuravnoteženega materialnega razvoja sodobnega človeštva, v katerem je antropogena preobrazba prešla $v$ degradacijsko fazo, kot posledico (skupno rezultanto) neuravnoteženega, prekomernega obremenjevanja okolja glede na samočistilne zmogljivosti okolja. Splošen dvig materialnega blagostanja sodobnega človeštva je bil dosežen tudi na račun degradacije okolje, njegovih sestav. S povratnimi loki pa degradirano geografsko okolje zmanjšuje kakovost bivanja, pospešuje izčrpavanje virov okolja, zmanjšuje biotsko pestrost in povzroča podnebne spremembe.

Ker se s tem zmanjšuje kakovost življenja sedanje in tudi prihodnjih generacij, je upravičeno vprašanje: ali je večplastno in medgeneracijsko primerno, da sodobno »zahodno« civilizacijo, ki zaradi linearnega modela razvoja pospešuje entropijo in s tem degradacijo okolja ter izumiranje drugih vrst, opredeljujemo kot razvojno fazo (vzpenjajočo civilizacijsko stopnico), ki si (še) prisluži oznako napredka? Ali kot napredek z vidika večplastno pojmovane kakovosti življenja in blagostanja geografija lahko označuje razvojno fazo materialno sicer bogate družbe, ki zaradi enostranskega linearnega razvoja (stalno povečevanje pozidanosti bioproduktivnih zemljišč in snovno-energetskih tokov v proizvodnji in potrošnji) tudi z nekaterimi nepovratnimi spremembami geografskega okolja, biosfere dolgoročno celo globalno ogroža geografske in biološke osnove preživetja človeške in drugih vrst? Prevlada linearnega družbenega in gospodarskega razvoja naj bi omogočila napredek, torej višjo, bolj zapleteno razvojno stopnjo pokrajine, dejansko pa je prišlo do degradacije pokrajine (urbane, kemizirane kmetijske), ki na eni strani brez dodatnih energetskih (antropogenih) vnosov ne more trajno delovati, hkrati pa dejansko zmanjšuje nosilno zmogljivost, samočistilne sposobnosti. Primerna je analogija s problemom modernizacije družbe, ki je enostransko pojmovana kot linearno zasnovan napredek, podobno kot je razvojni pristop napačno opredelil tako komunizem (marksizem) kot kapitalizem (Chodorkoff 2004).

Geografija lahko torej s pomočjo razvojnih faz pokrajine, geografskega okolja ne le razloži, temveč s pravočasnim prepoznavanjem zaskrbljujočih »okoljskih, pokrajinskih 
znamenj časa« čim bolj argumentirano, z veliko stopnjo verjetnosti in večplastno (sistemsko) pronicljivo diagnosticira stanje okolje, pokrajine in nakaže poti okoljskega zdravljenja, sonaravno pretehtanega regionalnega in prostorskega razvoja. Geografska razvojnovarovalna »uporabna« vrednost in meddisciplinska konkurenčnost izhaja iz predlogov načina prostorske organizacije, ki bo omogočila optimalno, sonaravno (»sopokrajinsko in sookoljsko«) kombinacijo linearne in tudi krožne vrste razvoja, torej spiralni razvoj pokrajine, geografskega okolja. Ključno pa je geografsko izhodišče, da v določeni pokrajini naravno in družbenogeogarfske značilnosti v medsebojni prepletenosti vedno vplivajo na človeka, njegovo delovanje, na razvoj (Lovrenčak 1999).

Nepovratno zasnovana raba zalog fosilnih goriv in pozidava odprtega prostora, onesnaženost pokrajin, geografskega okolja in njegovih sestavin je prispodoba sedanje prevlade tveganega linearnega razvoja sodobne civilizacije. Raba obnovljivih virov, reciklaža snovi, rekultivacija opuščenih in degradiranih zemljišč, prostorska in snovno-energetska učinkovitost in s tem povezano zmanjšanje pritiskov na okolje pa naj bi označevala prevlado prihodnjega krožnega razvoja in sonaravno, a dinamično pokrajinsko rabo kot zaželeno in možno geografsko rezultanto.

Uporaba besede napredek namesto razvoj je primernejša zaradi dejstva, ker se oznaka razvoj praviloma povezuje ali celo enači s količinsko zasnovano (gospodarsko) rastjo in s tem povezanim dvigom BDP. Gospodarski razvoj se praviloma enači z gospodarsko (količinsko) rastjo, čeprav je dejansko širši, saj obsega kvantitativne in tudi kvalitativne značilnosti. Govoreč o razvoju pa običajno mislimo pravzaprav na napredek, torej prehod z nižje stopnje kakovosti na višjo (Vintar Mally 2006, 11). Trajnostno sonaravni napredek človeštva in vsakega posameznika naj bi bil torej oznaka za kakovostno zasnovano izboljšanje vseh treh temeljnih sestavin blaginje, ekonomske, družbene (socialne) in okoljske, torej brez izčrpavanja okoljskega kapitala.

Ali je človekova okoljska trajnostnost in trajnostnost planeta možno danes sploh (še) doseči, ali smo dosegli na začetku 21. stoletja geografske meje planeta? Z geografskega vidika obravnave omejitev gospodarske in drugih oblik rasti je potrebno posebej podčrtati naslednje kritične geografske dejavnike (Marsh in Grossa 2002, 9):

1. prebivalstvo: $\mathrm{v}$ primeru manjšega števila prebivalcev in $\mathrm{s}$ tem povezanih potreb po življenjskem prostoru, vodi, energiji in hrani, bi bili okoljski problemi relativno majhni;

2. tehnologija: različni načini proizvodnje dobrin pomembno vplivajo na posege v okolje;

3. potrošništvo: označuje zmogljivost vsakega posameznika, da uporablja vse večjo količino naravnih virov (les, kovine, voda, zrak itd.);

4. raba zemljišč: različni tipi rabe zemljišč, predvsem zmogljivost kmetijske rabe, zlasti pa pozidave, ki nadomeščajo naravne sisteme in povzročajo motnje $\mathrm{v}$ okolju in njegovih sestavinah.

Kritični geografski dejavniki omejitev rasti so po svetu geografsko različno razporejeni in se medsebojno regionalno ločijo glede na razmere v geografskem okolju, naravnih virih in zmogljivosti ti. življenjskih oskrbnih sistemih. Navedene geografske realnosti se ali pa ne ujemajo $\mathrm{z}$ razporeditvijo prebivalcev in $\mathrm{z}$ njihovimi potrebami, željami, družbenimi vrednostmi in gospodarsko prakso. Rezultat so resni razkoraki med potrebami, pričakovanji 
prebivalcev in zmogljivostjo, omejitvami geografskega okolja, ki naj bi omogočili kritje potreb človeka v določeni regiji. Razkorak postaja vsako desetletje vse večji, saj se povečuje tako število prebivalcev kot raba zemljišč in/ali poraba naravnih virov na prebivalca.

Prepoznavanje razvojnih faze pokrajin, stanja in trendov geografskega okolja, torej prostorskih, pejsažnih ogledal sveta geografiji omogočajo občutljivo prepoznavanje (ne)sonaravnih izvijuganih poti in bližnjic blagostanja človeštva in pokrajinskih ekosistemov.

\section{VSEBINSKA ZASNOVA GEOGRAFIJE SONARAVNEGA RAZVOJA (NAPREDKA)}

Geografija kot prostorska veda oziroma veda o pokrajini, geografskemu okolju postavlja v ospredje udejanjanje načela okoljske trajnostnosti (obstoja še gospodarska in družbena) v sistemih poselitve, gospodarstva, infrastrukture in pokrajinske rabe, vključno s sonaravno rabo vseh virov okolja. S tega vidika označuje geografija sonaravnega razvoja iskanje trajnega sožitja med blagostanjem človeštva (razvojem, napredkom) in blagostanjem, trajnim delovanjem geografskega okolja. Geografija sonaravnega razvoja torej poudarja pomen pokrajinskim potezam in procesom čim bolj prilagojenega, sonaravnega vzorca poselitve, gospodarstva, infrastrukture in pokrajinske rabe, kot pomembne sestavine trajnega varstva in razvoja geografskega okolja. Izhaja torej iz dejstva, da je v obdobju po letu 1950 globalni gospodarski vnos na planetu narasel za pet-krat, izjemen gospodarski razvoj in dvig povprečnega blagostanja prebivalca planeta pa spremlja izrazita degradacija okolja in izčrpavanje virov okolja (Marsh in Grossa 2002, 3). Nadaljevanje dosedanjega razvojnega modela in nesonaravnega pokrajinskega vzorca bo povzročilo še večji obseg in intenzivnost pokrajinske degradacije.

Zato raziskovalno polje geografije sonaravnega razvoja:

1. podčrtuje težnjo "posnemanja« naravnih procesov oziroma čim večjega prilagajanja (načelo optimalnosti) poselitve, pokrajinske rabe, gospodarstva in infrastrukture naravnogeografskim in družbenogeografskim značilnostim določenega geografskega območja, pokrajine (ekosistema);

2. podčrtuje potrebo po ohranjanju virov okolja, pokrajinske in biotske raznovrstnosti, pospešeno uporabo reciklaže pri rabi snovi in nujnost prehoda na rabo obnovljivih energijskih virov, torej okoljske, pokrajinske razsežnosti trajnostnosti;

3. upošteva večjo ali manjšo entropičnost materialnih dejavnosti (sonaravne in ne »naravne« ali trajnostne dejavnosti), saj neskončen razvoj (količinsko večanje materialnega blagostanja) zaradi entropijske (ireverzibilne) narave materialnih dejavnosti človeka ni mogoč;

4. izhaja iz trditve, da je trajen proces prilagajanja materialne dejavnosti človeštva zmogljivostim narave (sonaravni razvoj), torej udejanjanje okoljske trajnostnosti, predpogoj udejanjanje gospodarske in socialne trajnostnosti in s tem udejanjanja načela dolgotrajnega (trajnostnega), večplastno pojmovanega humanega razvoja, bolje humanega napredka;

5. opredeljuje potrebo po sanaciji degradiranega geografskega okolja zaradi izboljšanja bivalnega okolja, virov okolja in varstva narave. 
Geografija sonaravnega razvoja se navezuje na spoznanja okoljske (ekološke) geografije (environmental-ecological geography) kot sintetične, aplikativne, pretežno regionalnogeografske (vključuje tudi spoznanja drugih vej geografije, fizične in družbene) discipline, ki se žariščno usmerja na celostno zasnovano preučevanje različnih prostorskih, pokrajinskih posledic preobrazbe (ožje-degradacije) geografskega okolja (diagnoza). Po mnenju Marsha in Grossa $(2002,14)$ je okoljska geografija usmerjena na raziskovanje različnih oblik degradacije okolja, kakovost globalnega okolja in življenjskih razmer. Proučuje torej različne sestavine okolja, človeško populacijo, rabo zemljišč in njihove medsebojne zveze, razmerja.

Okoljska geografija torej zlasti obravnava razmere, spremembe v okolju in kakovost življenja za človeštvo in druge organizme, torej degradacijo (geografskega) okolja, kakovost globalnega okolja in razmere za življenje človeške in drugih vrst. Posebno pozornost pa namenja tudi tistim dejavnostim rabe zemljišč, ki degradirajo naravne vire in okolje in s tem zmanjšujejo njegovo zmogljivost oskrbe življenja. Načrtovanje in udejanjanje organizacije materialne dejavnosti v okviru zmogljivosti geografskega okolja, optimalna raba virov okolja in ohranjanje pokrajinske raznovrstnosti ter sanacija degradiranega geografskega okolja pa so nosilni vsebinski stebri vsebine geografije sonaravnega okolja.

$\mathrm{S}$ sonaravnostjo v geografiji in sorodnih vedah dejansko podčrtujemo smernice, načine, ukrepe za tako zasnovano (sonaravno) materialno dejavnost, ki bo omogočala doseganje večplastnega želenega cilja - trajnostnost: v smislu čim daljšega (»trajnega«, bolje dolgotrajnega) ohranjanja pokrajinskega ravnovesja, višje kakovosti življenja in materialnega blagostanja ter večje socialne varnosti, skratka humanega napredka. Sonaravni razvoj (od šibkega k močnemu, strogemu) poselitve, gospodarstva, pokrajinske rabe in infrastrukture je torej »pot«, trajnostnost tudi z vidika okolja (okoljska trajnostnost) pa zaželeni končni cilj. Načelo okoljske trajnostnosti se naj bi v organizaciji materialnega življenja civilizacij, držav, regij, občin odražala $v$ približevanju, posnemanju načina in delovanja organizacije geografskih struktur poselitve, dejavnosti, infrastrukture in pokrajinske rabe delovanju narave, pokrajine. Velja prisluhniti opozorilu Matthewsa in Herberta $(2004,89)$, da fizičnogeogarfska/družbenogeografska dihotomija ni primerna izhodiščna, startna točka! Za geografijo je njeno možno »sonaravno« preoblikovanje priložnost, saj povezuje ekološko (okoljsko) prožnost, družbeno blagostanje in ekonomsko osnovo. Geografija ima tudi priložnost, da odkriva merljive kazalce, ki odražajo kontruktivno povezanost navedenih vsebinskih polj geografije in so primerni za eko-socialne razmere. Geografi lahko glede na bogate zgodovinske izkušnje kombinirajo, povezujejo izkušnje fizične- in družbene geografije in tako dejansko testirajo enotnost geografije od lokalne preko regionalne do globalne ravni (O'Riordian 2004). Tako npr. geograf Murdoch $(2006,127)$ poudarja, da ti. ekološka kompeksnost poudarja medsebojno povezanost in potrebo varovanja tako podeželja kot tudi urbanih območij.

Na splošno, torej ne zgolj za potrebe geografije in sorodnih ved, je uporaba pojma sonaravni razvoj oziroma sonaravni napredek glede na vsebino primerna za označevanje načina udejanjanja načela okoljske (naravovarstvene in okoljevarstvene) trajnostnosti. V geografiji sonaravni razvoj (napredek) pomeni usmeritev prostorskega, gospodarskega in regionalnega razvoja v okviru (različnih) zmogljivosti (omejitev) geografskega okolja, pokrajine. Obsega 
razvoj poselitve, gospodarstva, infrastrukture in pokrajinske rabe hkrati $\mathrm{z}$ varstvom (bivalnega) okolja, varstvo naravnih virov, varstvo narave oziroma ohranjanje pokrajinske, ekosistemske, vrstne pestrosti. Torej označuje okoljevarstveno in naravovarstveno sprejemljivo stopnjo in obseg antropogene preobrazbe geografskega okolja.

Geografija ima na razpolago številna orodja za doseganje sonaravnosti, udejanjanje sonaravnega razvoja. Ekonomisti poudarjajo, da je za dvig materialnega blagostanja ključen pospešen razvoj. Vendar številni primeru kažejo, da konvecionalni razvojni model ni trajnosten, sonaraven. Geografija nudi naslednja ključna orodja za doseganje trajnostno sonaravnega razvoja (Marsh in Grossa 2002; Matthews in Herbert 2004; O'riordan, 2004):

1. Sonaravni razvoj mora biti zasnovan na ohranjanju trajnih baz virov okolja, ki pa se po svetu geografsko zelo razlikujejo. Vsako načrtovanje in udejanjanje razvoja na državni (in regionalni ter lokalni) ravni mora torej upoštevati geografsko edinstvenost, geografske razvojne možnosti in omejitve (npr. vodne vire za kmetijstvo, lesni prirastek).

2. Sonaravni razvoj ne sme biti v konfliktu z lokalno kulturo in obstoječim družbenim (socialnim) redom, ki vključuje prakso rabe zemljišč, lokalno oblast, vidike religije, trgovskih navad itd. Sonaravna raba zemljišč je možna zgolj v primeru, da izhaja iz lokalnih pobud. Geografija lokalne identitete (npr. večja lokalna samoskrba s hrano) lahko veliko prispeva $\mathrm{k}$ lokalni in regionalni sonaravnosti.

3. Geografske sonaravne raziskave naj bodo usmerjene tako na odkrivanje značilnosti in obsega koristi kot tudi negativnih posledic človekovih posegov od lokalne preko regionalne do planetarne razsežnosti. Verjetno je regionalno prostorska raven največja geografska niša.

Tako npr. sonaravno zasnovane geografske raziskave gospodarskega razvoja regij za zmanjševanje podjetniških stroškov regije razen tradicionalnih načinov (razvoj infrastrukture in dvig izobrazbe) kot pomemben gospodarski dejavnik območja predlagajo med drugim tudi izboljšanje kakovosti življenja v bivalnem okolju prebivalcev (Hanink 1997).

\section{SKLEP}

Zgodovina človeštva in propad številnih civilizacij kaže, da v obdobjih zmanjševanja možnosti oskrbe z naravnimi viri človeštvo ni bilo sposobno zmanjšati materialne potrebe, obratno. V želji, da se ne bi zmanjšala njihova razvojna tekmovalnost, so še povečevali prekomerno rabo naravnih virov in okoljsko degradacijo. Odgovor na vprašanje ali bo človeštvo v 21. stoletju sposobno doseči sonaravno ravnovesje s planetom, bo odvisen od prebivalstvenih trendov, rabe in razvoja tehnologij, stopnje potrošništva, načina gospodarjenja rabe zemljišč (Marsh in Grossa 2002, 13).

Ključno sonaravno geografsko izhodišče za materialno organizacijo življenja človeške vrste na Zemlji kot zgolj energetsko odprtem (trajni, blagodejni priliv sončne energije) in snovno dejansko zaprtem sistemu je naslednje: planetarna in regionalna prilagoditev števila prebivalcev, potrošništva, tehnologije, rabe zemljišč, torej poselitve, dejavnosti, infrastrukture in pokrajinske rabe končnim nosilnim zmogljivostim geografskega okolja. Za dosego trajne (bolje- zaradi entropijskega zakona - dolgoročne!) sonaravnosti materialnega delovanja pa 
razen prepoznavanja in prilagajanja kritičnim geografskim dejavnikom potrebujemo tudi dolgoročne, sonaravno zasnovane planske programe. Koncept trajnostnosti/sonaravnosti (sustainability) je bil po mnenju geografa Kempa $(2004,143)$ dejansko vedno sestavina vseh naravnih sistemov in se odraža $\mathrm{v}$ njihovih karakterističnih ravnovesjih, $\mathrm{v}$ kontrolnih mehanizmih snovi in energije. S pojmom okoljska trajnostnost/sonaravnost želimo v geografiji torej zlasti podčrtati nujnost trajnega in stalnega dinamičnega prilagajanja (posnemanja) materialne dejavnosti človeka geografskemu okolju, ki se tudi antropogeno spreminja.

V okviru novega nastajajočega vsebinskega polja pa ti. geografija sonaravnega razvoja (napredka) na globalni, regionalni in lokalni ravni suvereno snuje geografskim značilnostim prilagojene, sonaravne pokrajinske vzorce poselitve, dejavnosti, rabe zemljišč. Geografija sonaravnega razvoja, teoretično in metodološko opremljena s večstoletno tradicijo regionalnogeografskega, fizičnogeografskega in družbenogeografskega preučevanja razmerij med družbo in geografskim okoljem, odkriva, razlaga in išče poti za trajnejše zmanjševanje razkoraka med različnimi geografskimi zmogljivostmi okolja na eni strani in razvojnimi potrebami prebivalcev, vključno s potrebo po prostorski prezaporeditvi vode, hrane, goriv, tehnologij, pa tudi prebivalstva. Vizionarsko je bilo razmišljanje modernizatorja geografije Haggetta (1972, 461): geografija ima tradicijo in potencial za iskanje srednje, optimalne poti med izkoriščanjem in onesnaževanjem naravnega okolja zaradi kratkoročnih ekonomskih (razvojnih) koristi in nerealističnega sanjarjenja o pastoralnem, v celoti zaščitenem, a neproduktivnem svetu. Geografija naj bi bila sposobna tudi predvideti posledice doseganja blagostanja (razvoj-napredek) v različnih lokalnih razmerah ali prostorskih razmestitvah (okolje).

Tudi geografija kot znanstvena veda o pokrajini, geografskemu okolju ima veliko priložnost, da torej strokovno argumentirano in samozavestno ponudi različne sonaravne poti in vzorce prostorske organizacije človekovih dejavnosti pokrajinsko mozaičnega planeta. Koncept trajnostnosti/sonaravnosti je po mnenju Matthewsa in Herberta (2004) tako priložnost kot tudi test enotnosti pogosto razdrobljene geografije. Potrjuje, da ostajajo interakcije med okoljem in družbo ključni povezujoči koncept za geografijo kot znanstvenoraziskovalno disciplino.

\section{Viri in literatura}

Brown, L., 2006. Plan B 2.0: Rescuing a Planet under Stress and a Civilization in Trouble. Earth Policy Institute, New York.

Chodorkoff, D., 2004. Redefining Development. Ekorega, Ljubljana.

Geografski terminonoški slovar. 2005. ZRC SAZU, Ljubljana.

Gilpin, A., 1996. Dictionary of Environment and Sustainable Development. John Willey and Sons, Chichester.

Haggett, P., 1972. Geography: A Modern Synthesis. Harper and Row. New York.

Hanink, D., 1997. Principles and Application of Economic Geography. John Wiley and Sons, New York.

Hudson, R., 2000. Production, Places and Environment. Prentice Hall, Harlow.

Ilešič, S., 1979. Pogledi na geografijo. Partizanska knjiga, Ljubljana. 
Kemp, D., 2004. Exploring Environmental Issues-An Integrated Approach. Routledge, London and New York.

Klemenčič, M. M., 1997. Geografski prehod. Dela 12, Ljubljana, str. 15-29.

Kupchella, C., Hyland, M., 1996. Environmental Science. Prentice - Hall, London.

Lah, A., 2002. Okoljski pojavi in pojmi. Svet za varstvo okolja Republike Slovenije, Ljubljana.

Lovrenčak, F., 1999. Naravnogeografske značilnosti kot možnosti razvoja Slovenije. Dela 14, Ljubljana, str. 27-44.

Macarol, B. 2001. Pravilna raba okoljske terminologije. Moravske Toplice.

Marsh, W., Grossa, J., 2002. Environmental Geography. Wiley, New York.

Matthews, J., Herbert D., 2004. Introduction. Unifying Geography. Routledge, London and New York.

Murdoch, J., 2006. Post-structuralist Geography. Sage Publications, London.

Pirnat, J., Anko B., 2001. Znanost o okolju (skripta). Biotehniška fakulteta, Ljubljana.

Plut, D., 1998. Varstvo geografskega okolja. Oddelek za geografijo, Filozofska fakulteta, Ljubljana.

Plut, D., 2004. Zeleni planet? Prebivalstvo, energija in okolje v 21. stoletju. Didakta, Radovljica.

Plut, D., 2005. Teoretična in vsebinska zasnova trajnostno sonaravnega napredka. Dela 23, Ljubljana, str. 59-114.

O'Riordian, T., 2004. Beyond Environmentalism: Towards Sustainability. Unifying Geography. Routledge, London and New York.

Our Commonn Future. 1987. World Commission on Environment and Development, Oxford University Press, Oxford-New York.

Radej,B.,2001.Odkonvencionalnega ekonomskegarazvojaktrajnostnemu-implementacijske teze. IB revija 2001/4. Ljubljana, str. 7-11.

Radinja, D., 1972. Onesnaženost človekovega okolja v luči geografske terminologije. Geografski obzornik 1972/4, Ljubljana, str. 35 - 39.

Radinja, D., 1974. Geografija in varstvo človekovega okolja. Geografski vestnik 45, Ljubljana, str. $110-120$.

Radinja, D., 1987. Varstvo geografskega okolja in geografija. Zbornik 14. zborovanja slovenskih geografov, Ljubljana, str. $19-22$.

Slovenski pravopis. 2001. SAZU in ZRC SAZU, Ljubljana.

Špes, M., 1994. Degradacija okolja kot dejavnik diferenciacije urbane pokrajine (na izbranih slovenskih primerih) (doktorska disertacija). Oddelek za geografijo, Filozofska fakulteta, Ljubljana.

Špes, M., Cigale, D., Lampič, B., Natek, K., Plut, D., Smrekar, A., 2002. Študija ranljivosti okolja. Geographica Slovenica 35/1-2, Ljubljana.

Vintar Mally, K., 2006. Okoljevarstvena in socialnoekonomska protislovja držav v razvojo (doktorska disertacija), Oddelek za geografijo, Filozofska fakulteta, Ljubjana.

Vovk Korže, A., 1997. Spreminjanje pokrajine zaradi posegov človeka. Geografija v šoli VI/ 2 - 3, Ljubljana, str. $100-104$. 


\section{SUSTAINABLE DEVELOPMENT (PROGRESS) AND GEOGRAPHY}

\section{Summary}

The great majority of scholars believe that the present growth of economy and development models cannot last forever. Besides, it is urgent to develop new approaches to the use of space and environmental resources. Will the humanity be able to reach the sustainable balance with the planet in the $21^{\text {st }}$ century? The answer will depend on the population trends, the use and development of technologies, the degree of consumption, the mode of managing the land use.

The key sustainable geographical point of departure for the material organization of life of the human race on the Earth as an energy open (permanent, beneficent inflow of solar energy) and materially actually closed system, is: the planetary and regional adjustment of the number of population, of consumption, technology, land use - that means of the settling, activities, infrastructure and landscape use - to the utmost carrying capacities of geographical environment. In order to achieve a lasting (better to say: long-term!, because of the principle of entropy) sustainability of material functioning, in addition to the identification of and adjustment to critical geographical factors, we also need long-term programmes planned in accordance with sustainability. With the idea of environmental sustainability geography would, in the first place, like to stress the requirement for a continuous and stable dynamic adjustment (imitation) of material activity of humans to geographical environment, which is also subject to anthropogenic changes.

Within the framework of a newly, emerging contents-related field, the so-called geography of sustainable development (progress) devises in a sovereign manner on the global, regional and local levels, sustainable landscape patterns of the settling, activities and land use adjusted to geographical features. Geography of sustainable development - in terms of theory and methodology furnished with century-long tradition of regional-geographical, physical-geographical and human-geographical researches into the relations between society and geographical environment - discovers, explains and searches the ways for a more stable diminishing of the gap between various geographical capacities of the environment on the one hand, and on the other, developmental needs of inhabitants, including the need for a spatial redistribution of water, food, fuels, technologies and also the population. Considerations of Haggett (1972), the modernizer of geography, were truly visionary: geography has the tradition and the potential to find the middle, i.e. the optimum way between exploitation and pollution of natural environment because of short-term economic (developmental) benefits on the one hand, and unrealistic dreams about the pastoral, completely protected but non-productive world on the other. Geography is supposedly also capable of foreseeing the consequences of the achieving of welfare (development) in different local conditions and spatial distribution (environment).

In geography, the sustainable development (progress) means to keep the spatial, economic and regional developments within the framework of (different) capacities (limitations) of the geographical environment, or the landscape. It includes the developments of settling, eco- 
nomy, infrastructure and landscape use, together with the protection of (dwelling) environment, conservation of natural resources, nature conservation or the conservation of landscape-, ecosystem- and species diversities. So it denotes the acceptable degree and extent of anthropogenic transformation of geographical environment in view of environmental protection and nature conservation. Also geography, as the science about the landscape, or geographical environment, has a good chance to authoritatively offer different ways and patterns, supported with expert arguments, of spatial organization of human activities in the mosaic of landscapes on our planet. The concept of sustainability is both a chance for and a test of the unity of geography that is so often fragmented. It corroborates the fact that interactions between the environment and the society remain the key unifying concept of geography as a scientific-research discipline. Thanks to the scientific-research advantages of geography, it is reasonable to pay greater attention to environmental sustainability from the aspect of sustainable and developmentally devised geographical accents (spatial and regional development), towards the new area of research and the curriculum subject - geography of sustainable development/progress. 